\title{
QANE AFI

\section{CASN/ACESI: 75 years with an eye on quality nursing education - L'ACESI/CASN : Un regard sur la qualité de la formation en sciences infirmières depuis 75 ans}

Jacinthe I. Pepin

Université de Montréal, jacinthe.pepin@umontreal.ca

Florence Myrick

amyrick@ualberta.ca

Follow this and additional works at: https://qane-afı.casn.ca/journal

\section{Recommended Citation}

Pepin, Jacinthe I. and Myrick, Florence (2018) "CASN/ACESI: 75 years with an eye on quality nursing education L'ACESI/CASN : Un regard sur la qualité de la formation en sciences infirmières depuis 75 ans," Quality Advancement in Nursing Education - Avancées en formation infirmière: Vol. 4: Iss. 1, Article 9.

DOI: https://doi.org/10.17483/2368-6669.1165

This Interview is brought to you for free and open access by Quality Advancement in Nursing Education - Avancées en formation infirmière. It has been accepted for inclusion in Quality Advancement in Nursing Education - Avancées en formation infirmière by an authorized editor of Quality Advancement in Nursing Education - Avancées en formation infirmière. 


\section{CASN/ACESI: 75 years with an eye on quality nursing education}

\section{L'ACESI/CASN : Un regard sur la qualité de la formation en sciences infirmières depuis} 75 ans
Interviewee: Dr. Cynthia Baker is the Executive Director, Canadian Association of Schools of Nursing (CASN) /Association canadienne des écoles de sciences infirmières (ACÉSI)

Interviewer: Dr. Jacinthe Pepin, Co-Editor-inChief

Dr. Pepin: Before we begin, I would like to thank you, on behalf of my Co-Editor-in-Chief, Dr. Florence Myrick, and me for taking the time to participate in this interview on the occasion of the $75^{\text {th }}$ anniversary of the Canadian Association of Schools of Nursing/Association canadienne des écoles de sciences infirmières (CASN/ACÉSI), that was celebrated in November 2017.

CASN/ACÉSI, the national voice for nursing education, research, and scholarship, established its mission as one of leading nursing education and nursing scholarship in the interest of healthier Canadians. In this particular interview we would like to emphasize its role specific in quality nursing education.

We would like to ascertain from you Dr. Baker, as the Director of CASN, what would you say are the major quality nursing education milestones or the landmarks of CASN? We have identified three, but we would like to know your perspective and if you agree with these three. Specifically, why would you identify these as being the landmarks for quality education? The three landmarks to which I am referring are the Accreditation Program, the journal Quality Advancement in Nursing Education/Avancées en formation infirmière (QANE-AFI), and the Canadian Nurse Educator Institute/L'Institut canadien des infirmières enseignantes (CNEI/ICIE).

Dr. Baker: I would agree, I believe each of these have been significant in promoting high-quality nursing education and in advancing nursing
Invitée : $D^{\text {re }}$ Cynthia Baker est directrice générale de l'Association canadienne des écoles de sciences infirmières (ACESI)/Canadian Association of Schools of Nursing (CASN)

Intervieweuse : $D^{r e}$ Jacinthe Pepin, Corédactrice en chef

$D^{\text {re }}$ Pepin : Avant de commencer, ma corédactrice en chef, la $\mathrm{D}^{\text {re }}$ Florence Myrick, et moi aimerions vous remercier d'avoir pris le temps de participer à cette entrevue à l'occasion du $75^{\mathrm{e}}$ anniversaire de 1'Association canadienne des écoles de sciences infirmières (ACESI)/ Canadian Association of Schools of Nursing (CASN), célébré en novembre 2017.

L'ACESI/CASN, porte-parole national de la formation, de la recherche et de l'avancement des connaissances en sciences infirmières, a pour mission d'assurer une meilleure formation et un avancement constant des connaissances en sciences infirmières afin d'optimiser la santé des Canadiens. Au cours de cet entretien, nous aimerions souligner son rôle en ce qui concerne la qualité de la formation infirmière.

$\mathrm{D}^{\text {re }}$ Baker, en tant que directrice de l'ACESI, que considérez-vous comme étant les principaux jalons de la qualité de la formation en sciences infirmières posés par l'ACÉSI ou ses projets les plus marquants? Nous en avons identifié trois, mais nous aimerions vous entendre, question de savoir si vous êtes d'accord avec nous. Plus précisément, pourquoi les considérez-vous comme étant les projets phares de promotion d'une formation de qualité? Je fais référence ici au Programme d'agrément, à la revue scientifique Quality Advancement in Nursing Education/Avancées en formation infirmière $(Q A N E-A F I)$ et à l'Institut canadien des infirmières enseignantes (ICIE)/Canadian Nurse Educator Institute (CNEI). 
knowledge. This is CASN's mission, CASN's mandate, and CASN's raison d'être, and has been since its inception in 1942.

Accreditation is recognized internationally as a key mechanism for advancing the quality of health professional education from a systems level. As far as $Q A N E-A F I$ is concerned, it provides an excellent forum in which educators can address questions specifically related to the raison d'être of CASN, the advancement of quality in nursing education, and also the advancement of knowledge development in this particular field.

And you mentioned the Canadian Nurse Educator Institute. CNEI offers online continuing education opportunities that serve to enhance pedagogy and scholarship. It also offers a national certification program in nursing education, a certification program for clinical instructors, and a new certification program in simulation pedagogy. These initiatives are very much related to CASN's mandate to foster excellence in nursing education.

Dr. Pepin: Thank you very much for confirming that these initiatives are the major milestones of CASN. And we will address each of them individually, beginning with the Accreditation Program. Can you explain how the Accreditation Program plays a crucial role in quality advancement in nursing education and how far the program has come to be integrated throughout Canada?

Dr. Baker: In terms of accreditation being a mechanism for advancing the quality of health professional education, a key reason for this is its emphasis on continuous quality improvement. While I can provide a detailed description of accreditation, I think the core aspect to highlight is that it is based on national standards of excellence and thus it clarifies what the expectations are. It also involves a peer review, which includes a panel of judges making a judgement about the quality of a program, but most importantly this panel also provide recommendations and require follow-up on the recommendations.

So this process really does enhance excellence of nursing education nationally. Currently $93 \%$ of
D ${ }^{\text {re }}$ Baker : Je suis d'accord. Chacune de ces entités a joué un rôle important dans la promotion d'une formation infirmière de haute qualité et dans l'avancement des connaissances en sciences infirmières. C'est la mission, le mandat et la raison d'être de l'ACESI depuis sa création en 1942.

L'agrément est reconnu internationalement comme un mécanisme clé pour faire progresser la qualité de la formation des professionnels de la santé d'une manière systémique. En ce qui concerne la revue $Q A N E-A F I$, elle constitue un excellent forum pour que les éducateurs puissent aborder des questions liées à la raison d'être de l'ACESI, à l'avancement de la qualité dans la formation infirmière ainsi qu'au développement des connaissances dans ce domaine.

Vous avez mentionné l'ICIE, qui offre des possibilités de formation continue en ligne pour améliorer la pédagogie et le développement des compétences de professeurs-chercheurs. Il offre également un programme national de certification en formation infirmière, un programme de certification pour les enseignantes cliniques et un nouveau programme de certification en pédagogie de la simulation. Ces initiatives sont étroitement liées au mandat de l'ACESI qui vise à favoriser l'excellence en formation infirmière.

$D^{\text {re }}$ Pepin : Merci de confirmer que ces initiatives sont effectivement les principaux jalons posés par l'ACESI. Nous aimerions aborder chacun de ceux-ci individuellement, en commençant par le Programme d'agrément. Pouvez-vous nous expliquer comment ce programme joue un rôle crucial dans l'avancement de la qualité de la formation en sciences infirmières et dans quelle mesure il a évolué pour être intégré à l'échelle canadienne?

$D^{\text {re }}$ Baker : L'agrément est un mécanisme de promotion d'une formation de qualité pour les professionnels de la santé principalement parce qu'il met l'accent sur l'amélioration continue de la qualité des programmes. Bien que je puisse fournir une description détaillée de l'agrément, je pense que l'aspect essentiel à souligner est qu'il est fondé sur des normes nationales d'excellence qui présentent des attentes claires. 
CASN member schools of nursing in Canada offering baccalaureate degrees undergo accreditation reviews on a regular basis. We have witnessed the positive impact accreditation has had on the quality of schools that have been reviewed over the years. I would argue that we have really seen many nursing education programs in Canada flourish as a result of the CASN Accreditation Program.

If you would permit me, I would like to set the Accreditation Program in the context of CASN's history, if I may.

A precursor of the accreditation program was behind the scenes from the very beginning of CASN. Advancing the quality of nursing education was the mission adopted by the small band of university nurse educators from across Canada who met at the Windsor Hotel in Montreal, in June 1942 "to take Council from one another". They went home having formed the initial CASN organization, and they set for themselves the key objectives of delineating desirable standards for university schools of nursing to meet, and to improve the standards of existing schools of nursing in the country. Although they set other objectives for the organization, these were really the key ones for the organization. So the Accreditation Program concurs directly with the founders' initial vision. In fact, they immediately began to develop national standards for university schools of nursing in Canada and in 1957 the organization published a precursor to the CASN Accreditation Program. It was a booklet entitled, "Desirable Standards for Canadian Schools of Nursing Normes souhaitables pour les écoles de sciences infirmières canadiennes". In this booklet, they addressed the educational preparation of faculty, resources, the classroom infrastructure, and teaching. Their next step, which did take several decades, was to convert this endeavour into a full-fledged educational program. The conversion was a slow process. The dedicated educators who were charged with achieving this had no email at their disposal. They did not have Dropbox. They could not avail themselves of Go to Meeting, nor Skype, and they lived in different provinces across Canada. Through their ardent efforts, however, the goal was reached,
Il comporte également un processus d'évaluation par les pairs, incluant un jury dont les membres se prononcent sur la qualité des programmes, mais surtout, ce jury fournit des recommandations et demande un rapport de suivi de ces recommandations.

Ainsi, ce processus améliore vraiment l'excellence de la formation infirmière à l'échelle nationale. À l'heure actuelle, $93 \%$ des écoles canadiennes de sciences infirmières membres de l'ACESI et qui offrent des programmes de baccalauréat font régulièrement l'objet d'évaluations d'agrément. Nous avons été témoins de l'impact positif de l'agrément sur la qualité au sein des écoles de sciences infirmières qui ont été évaluées au fil des ans. Je dirais même que nous avons vu beaucoup de programmes de formation en sciences infirmières au Canada s'épanouir grâce au Programme d'agrément de l'ACESI.

$\mathrm{Si}$ vous me le permettez, j'aimerais remettre en contexte le développement du Programme d'agrément dans l'histoire de l'ACESI.

Un précurseur du Programme d'agrément était en préparation depuis la création de l'ACESI, lorsqu'un petit groupe d'infirmières professeures universitaires de partout au Canada se sont réunies à l'hôtel Windsor de Montréal, en juin 1942, pour «obtenir des conseils les unes des autres ». En effet, une fois l'organisation initiale de l'ACESI établie, elles ont adopté pour mission l'avancement de la qualité de la formation en sciences infirmières. Elles sont ensuite rentrées chez elles après avoir fixé comme objectif central de l'organisation de délimiter les normes souhaitables pour les écoles universitaires de sciences infirmières, normes qui devaient refléter et même excéder celles déjà établies par les écoles de sciences infirmières existantes à travers le pays. Bien qu'elles aient fixé d'autres objectifs, celui-ci était le plus important et donc le Programme d'agrément concorde parfaitement avec la vision initiale des fondatrices. En fait, ces dernières ont immédiatement commencé à élaborer des normes nationales pour les écoles universitaires de sciences infirmières au Canada. En 1957, l'organisation a publié une première version du 
and, in 1987, your university, Dr. Pepin, the University of Montreal, was the first school of nursing to achieve CASN accreditation.

Since then, I am pleased to report that the program has expanded by leaps and bounds. To summarize, with its emphasis on excellence and continuous quality improvement, we believe that the Accreditation Program has been instrumental in fostering high standards for nursing education in Canada.

Dr. Pepin: Dr. Baker, most recently, you were instrumental in facilitating the establishment of Quality Advancement in Nursing Education/Avancées en formation infirmière (QANE/AFI). Can you share with us why you thought this journal to be an important endeavor within the context of CASN?

Dr. Baker: The purpose in creating this bilingual, peer-reviewed journal was very much in-line with the objectives of CASN's founding members.

From its inception, CASN has been a bilingual organization, and so the bilingual aspect of the journal is also very much in keeping with our history and with the initial vision of the organization.

By providing a forum in which educators can address questions related to advancing the quality of nursing education, our aim was to create a vehicle that would promote excellence in nursing pedagogy through the publication of research, theoretical papers, policy papers, and so on. The aim was to create a vehicle that would advance scholarship and knowledge in nursing education.

Dr. Pepin: Dr. Baker, we learned that you were the initiator of the Canadian Nurse Educator Institute. Can you share with us your impetus for creating the Institute and how you envision the Institute evolving in the future?

Dr. Baker: This institute evolved out of a series of CASN initiatives designed to enhance the quality of nursing education through online continuing education courses, various retreats that we were offering, and through webinars that we were providing. By formalizing these initiatives into an Institute, with an advisory
Programme d'agrément de l'ACESI, soit une brochure intitulée Desirable Standards for Canadian Schools of Nursing - Normes souhaitables pour les écoles de sciences infirmières canadiennes, qui traitait de la préparation pédagogique des professeures, des ressources, de l'infrastructure des classes et de l'enseignement. Elles ont mis plusieurs années avant de franchir l'étape suivante, soit la conversion de cette initiative en un programme d'évaluation à part entière. Les professeures responsables d'atteindre cet objectif n'avaient pas de courrier électronique à leur disposition, ni de Dropbox, donc le tout a été effectué très lentement. Elles ne pouvaient pas se prévaloir du logiciel Go to Meeting ni de Skype, et elles vivaient dans différentes provinces canadiennes. Grâce à leur ardeur et à leur persévérance, toutefois, l'objectif a été atteint et, en 1987, votre université, $\mathrm{D}^{\text {re }}$ Pepin, 1'Université de Montréal, a été la première faculté de sciences infirmières à obtenir l'agrément de l'ACESI.

Depuis lors, je suis heureuse d'annoncer que le programme s'est étendu de façon exponentielle. Pour résumer, en mettant l'accent sur l'excellence et l'amélioration continue de la qualité, nous croyons que le Programme d'agrément a contribué à promouvoir des normes élevées pour la formation infirmière au Canada.

$D^{\text {re }}$ Pepin : $\mathrm{D}^{\text {re }}$ Baker, tout récemment, vous avez contribué à la mise en place de la revue scientifique $Q A N E-A F I$. Pouvez-vous nous dire pourquoi vous croyez que cette revue est une initiative importante pour l'ACESI?

$D^{\text {re }}$ Baker : La raison d'être de cette revue bilingue évaluée par des pairs est tout à fait conforme aux objectifs des membres fondatrices de l'ACESI.

Depuis sa création, l'ACESI est bilingue, alors la dualité linguistique de la revue s'intègre parfaitement à notre histoire et à la vision initiale de l'organisation.

En fournissant aux professeures un forum où elles peuvent aborder des questions liées à l'avancement de la qualité de la formation infirmière, notre objectif était de favoriser l'excellence en pédagogie infirmière par la publication, de recherches, d'articles théoriques, 
board of internationally respected nurse educators and scholars to guide it, the goal and indeed the vision was to create high-quality learning opportunities and certification programs specific to nurse educators. We also envisioned advancing this vision and creating a centre of excellence in nursing education that will, in turn, have an impact internationally as well as nationally.

Dr. Pepin: And how do you envision the Institute evolving in the future?

Dr. Baker: We have three certification programs for educators that I mentioned earlier which are a central focus of the Institute: nurse educator, clinical instructor, and simulation pedagogy. We see these evolving in line with advancing knowledge in these fields. Regarding the online continuing education courses, we see these evolving in response to changing needs of nurse educators Similarly, the webinars and lunch \& learn series which we are providing will also continue to evolve in response the educational and scholarship needs of faculty across Canada.

Dr. Pepin: Clearly, it is really at the pedagogical teaching and learning dimension. Thank you. Also there is the fact that you honour some scholars in nursing education through the Fellows of the Institute. Can you elaborate somewhat?

Dr. Baker: Yes, the Fellowship is an opportunity to highlight and emphasize the value that nursing education scholars are having on education. I think this is an important role of the Institute.

Dr. Pepin: Thank you for addressing the three major milestones that have emerged with regard to quality nursing education programs as developed by CASN. Dr. Baker, what do you foresee as the major quality nursing education challenges for the next 75 years. I realize my question is asking you to project well into the future; however, can you speculate as to what you foresee those challenges to be?

Dr. Baker: CASN was created because nursing education needed to undergo a process of evolution to meet changing health care needs. At the time, nursing education was in a context that de documents de politiques ou autres. L'idée était de faire progresser le développement des connaissances et le scholarship en formation en sciences infirmières.

$D^{\text {re }}$ Pepin : $\mathrm{D}^{\text {re }}$ Baker, nous avons appris que vous étiez également l'initiatrice de l'Institut canadien des infirmières enseignantes (l'ICIE). Quelle a été votre motivation pour créer l'ICIE et comment envisagez-vous son évolution?

$D^{\text {re }}$ Baker : L'ICIE est né d'une série d'initiatives de l'ACESI visant à améliorer la qualité de la formation en sciences infirmières grâce à des cours de formation continue en ligne, à divers séminaires que nous offrions et aux webinaires que nous organisions. En officialisant ces initiatives et les regroupant dans un institut, guidé par un conseil consultatif d'infirmières enseignantes et d'universitaires respectées à l'échelle internationale, nous avons établi un objectif et une vision, soit de créer des occasions d'apprentissage et des programmes de certification spécifiques aux infirmières enseignantes, de haute qualité. Nous avons également envisagé de faire progresser cette initiative vers la création d'un centre d'excellence en formation infirmière qui, à son tour, aurait un impact à l'échelle nationale et internationale.

$D^{\text {re }}$ Pepin : Comment envisagez-vous l'évolution de l'ICIE?

D $^{\text {re }}$ Baker : J'ai mentionné plus tôt trois programmes de certification que nous offrons aux formatrices en sciences infirmières au sein de l'Institut: infirmières enseignantes, enseignantes cliniques et pédagogie de la simulation. Nous prévoyons qu'ils évolueront en fonction de l'avancement des connaissances. En ce qui concerne les cours de formation continue en ligne, nous les voyons évoluer en réponse aux besoins changeants des enseignantes en sciences infirmières. De même, les webinaires et les déjeuners-conférences que nous offrons continueront d'évoluer selon les besoins en formation auxquels font face les écoles de sciences infirmières du Canada.

$D^{\text {re }}$ Pepin : De toute évidence, ces programmes visent la dimension pédagogique ou de formation et d'apprentissage. Merci! Vous honorez 
was inadequate and nursing educators were endeavouring to improve the quality of nursing education.

In my experience as an educator, nursing education has always had to advocate strongly for quality in nursing education. I have seen it consistently challenged by other forces.

Looking ahead, I believe CASN will continue to need to advocate for quality in nursing education. There are always forces in play to reduce nursing education standards and to diminish the academic preparation nurses require to provide the level of care Canadians need. In addition, I think the need for high-quality nursing education has grown exponentially as the complexity of the practice of nursing has increased, and I expect it will continue to do so in the future. The quality of nursing education has always been important for the health of Canadians and I believe it will continue to be. I guess, projecting into the future, CASN will need to continue to fight for excellence in nursing education.

Dr. Pepin: Do you see the challenges as evolving from fewer resources?

Dr. Baker: The challenges have always had a financial base.

Dr. Pepin: CASN has always promoted the development of nursing research. Tell us how you this as still being important in the organization? In other words, how it is important to continue to support nursing research in general and in particular research in nursing education?

Dr. Baker: Nursing research in general, I think, is hugely important, because research is about the advancement of knowledge. We need to continue to advance our knowledge base in nursing and I believe it is essential for CASN to continue to promote scholarship. It is worth mentioning in this context that the Accreditation Program has always fostered scholarship which is incorporated in its standards. I believe it is also worth celebrating the substantial increase in scholarship that we are seeing in numerous Canadian schools of nursing across the country. également des chercheures en formation en sciences infirmières par l'intermédiaire du programme de Fellows ou Associées de l'Institut. Pouvez-vous nous donner plus de précisions?

$D^{\text {re }}$ Baker : L'association offre une occasion de souligner et de mettre en lumière la valeur de l'apport des chercheures en formation infirmière. Je pense que c'est un rôle important de l'Institut.

$D^{\text {re }}$ Pepin : Merci d'avoir décrit les trois jalons importants pour la qualité de la formation en sciences infirmières élaborés par l'ACESI. $\mathrm{D}^{\text {re }}$ Baker, quels seront, selon vous, les principaux défis pour la qualité de la formation en sciences infirmières dans les 75 prochaines années? Je sais que ma question demande de vous projeter loin dans l'avenir, mais pouvezvous prédire ce qu'ils seront?

$D^{\text {re }}$ Baker : L'ACESI a été créée parce que la formation infirmière avait besoin d'être revue pour répondre aux besoins changeants dans les soins de santé. À l'époque, le contexte de la formation en sciences infirmières n'était pas idéal et les enseignantes s'efforçaient d'améliorer la qualité de la formation qu'elles offraient. Selon mon expérience de professeure, le domaine de la formation en sciences infirmières a toujours dû plaider fortement pour sa qualité. Au fil des ans, je l'ai souvent vue mise à l'épreuve par diverses forces.

Je crois que l'ACESI devra continuer à plaider pour la qualité de la formation en sciences infirmières. Il y a toujours des forces en jeu pour réduire les normes de formation et diminuer le niveau de préparation académique qu'on exige des infirmières pour qu'elles fournissent le type de soins dont les Canadiens ont besoin. De plus, je crois que la nécessité d'une formation infirmière de haute qualité a augmenté exponentiellement avec la complexité de la pratique des soins infirmiers, et je m'attends à ce que cette tendance se maintienne. La qualité de la formation en sciences infirmières a toujours été primordiale à la santé des Canadiens et je crois qu'elle continuera de l'être. Je suppose qu'en prévision de l'avenir, l'ACESI devra continuer à se battre pour l'excellence en formation infirmière. 
Dr. Pepin: This particular point is important to highlight within the accreditation process including the expectation for publication. If people are encouraged to publish they will be encouraged to engage more readily in the scholarly process.

Dr. Baker: They are encouraged to publicly disseminate new evidence, new knowledge in peer reviewed forums be it journals or conferences.

Dr. Pepin: Thank you very much.
$D^{\text {re }}$ Pepin : Considérez-vous que les défis évoluent à partir d'un moins grand nombre de ressources?

$\mathrm{D}^{\text {re }}$ Baker : Les défis ont toujours eu une origine financière.

$D^{\text {re }}$ Pepin : L'ACESI a toujours favorisé le développement de la recherche infirmière. Quelle importance ce volet a-t-il encore dans l'organisation? En d'autres termes, pourquoi estce important de continuer à soutenir la recherche infirmière en général et la recherche en formation en sciences infirmières en particulier?

$D^{\text {re }}$ Baker : Je pense que la recherche infirmière en général est extrêmement importante, du fait qu'elle est nécessaire à l'avancement des connaissances. Je crois qu'il est essentiel que l'ACESI en poursuive la promotion puisque nous devons continuer d'améliorer notre corps de connaissances en sciences infirmières. Il convient de mentionner dans ce contexte que le Programme d'agrément a toujours favorisé le développement du scholarship des professeurs, un élément qui est incorporé dans ses normes. Je crois qu'il vaut également la peine de célébrer l'avancement considérable en matière de scholarship que nous observons dans de nombreuses écoles canadiennes de sciences infirmières.

$D^{\text {re }}$ Pepin : Il est important de souligner ce point particulier du processus d'agrément et les attentes quant à la publication. Si on encourage les professeures à publier, elles s'engageront nécessairement dans des activités de scholarship.

$D^{\text {re }}$ Baker : Elles sont encouragées à diffuser publiquement de nouveaux résultats de recherche et de nouvelles connaissances dans des forums évalués par des pairs, qu'il s'agisse de revues ou de congrès scientifiques.

$D^{\text {re }}$ Pepin : Merci infiniment. 